位相差分特性を考慮した設計用模擬地震動作成に関する研究

その $1 \quad$ 位相差分分布と地震動経時特性の関係に関する理論的背景

\title{
A STUDY ON A GENERATION OF SIMULATED EARTHQUAKE GROUND MOTION CONSIDERING PHASE DIFFERENCE CHARACTERISTICS
}

Part 1 Theoretical background of the relationship between phase difference distribution and envelope characteristics

山根 尚志*, 長 橋 純男**

Takashi YAMANE and Sumio NAGAHASHI

\begin{abstract}
The purpose of this paper is to demonstrate that the theoretical background of the similarity between the distribution of phase differences and the shape of the wave envelope can be clearly explained by using the concept of beat. The validity of this idea is verified by analyzing recorded earthquake motions. This idea, moreover, derives two significant results, that a wave with uniform phase differences becomes a pulse independently of Fourier amplitude, and that the position of the pulse on the time axis and the pulse type can be specified by the parameters of the phase difference and the initial phase angle. Comparing response spectra of two waves with identical Fourier amplitudes, it is illustrated that the response spectrum depends on Fourier phase as well as Fourier amplitude.
\end{abstract}

\author{
Keywords: Simulated earthquake ground motion, Fourier phase, Phase difference, \\ Envelope characteristics of time history, Beat, Pulse \\ 模趋地震動、フーリエ位相、位相差分、経時特性、うなり、パルス波
}

\section{1. 序}

高層建築物・免震建築物の地震応答解析では、例えば最大速度值 で規準化した観測地震動以外に、設計用に設定した目標応答スペク トルに適合する模擬地震動を作成し、これを入力地震動として用い ることがある。この模擬地震動の作成に関しては、与えられた目標 応答スペクトルに適合する時刻歷を正弦波の重ね合わせで求める 手法が一般的であるが、これは、時刻歴波形経時特性の設定方法と いう観点からみて以下の 2 種に大別することができる。一つは、位 相を一様乱数で与え、Jennings et al. ${ }^{1)}$ が定義した時刻歴包絡線を規 定して地震動を作成する手法所えば2)であり、もう一うは、位相とし て観測地震動の特性を採用する手法城えば3)である。前者では、人為 的に作成した位相特性・経時特性と、実現象としての地震動特性と の関係が明快とは言い難い。一方後者は実現象から位相を借用して いるため、位相特性という観点ではこのような問題は少ないと判断 でき、また、得られた時刻歴は位相を採用した原波形と非常に良く 似た形状となり、より現実的な地震動が作成されていると考えるこ とができる。しかしこの場合でも、位相を採用する地震動の選択基 準は明快ではなく、より論理的な考え方の提示が期待されている。 従来、設計用地震動に関する研究は振幅特性に重点が置かれ、位 相特性に関寸る研究は少なかったが、大崎ら ${ }^{4)}$ が、隣り合うフーリ
エ位相の差である位相差分分布と加速度時刻歴波形（以下、時刻歴 波形と称する。）の包絡形の類似性を指摘して以来、地震動の位相 特性と経時特性に関する研究が行われるようになってきた。和泉・ 勝倉 ${ }^{5)}$ は、フーリエ位相の傾きである群遅延時間の平均値と標準偏 差により、時刻歴波形の重心位置と広がりが表現できることを示し、 位相情報と波形の経時特性の関保を論じた。 木村 $\left.{ }^{6}\right)$ は群遅延時間を 用いた波形制御について考察し、特に、初期位相が局所的坡形形状 に大きな影響を与えることを指摘した。また沢田 ${ }^{7}$ は、位相差分分 布と経時特性の類似性に関する理論的根拠について検討し、回㷌分 析の手法を用いることにより、微小帯域の最大值生起時間が、その 帯域の位相差分の重みつき平均で表されることを示した。さらに沢 田ら ${ }^{8)}$ は、地震動継続時間と群遅延時間の関係についても検討して いる。

このような基礎的研究を踏まえ、位相差分分布、あるいは群遅延 時間を考虑した模擬地震動に関する研究が行われるようになって きた。石井ら "は、䧽測地震動の分析及び位相差分分布特性が応答 に与える影響に関する検討を行い、狭帯域の位相差分分布を考慮し た模挺地震動作成手法を提案している。また佐藤らは、群遅延時間 の平均値と標準偏差が、やや長周期地震動の経時特性を評価するた めの指標として適切であることを示し ${ }^{10)}$ 、地震動記録の回帰分析を
* 侏西建設計構造設計室 主查・工修

** 千葉工業大学工学部建築学科 教授. 工博
Senior Structural Engineer, Structural Engineering. Dept., Nikken Sekkei Ltd. M. Eng.

Prof., Dept. of Architecture, Chiba Institute of Technology; Dr. Eng 
基に震央距離をパラメータとしてこれら指標を統計的にモデル化

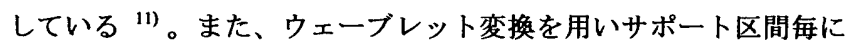
これら指標を求め、マグニチュードと震央距離により回帰分析を行 って設計用の標準的位相特性をモデル化した研究もある ${ }^{12), 13)}$ 。これ らは、震源から観測点までの複雑な特性を全体として捉え、マグニ チュードや震央距離という明解で一般的にも広く認知されている 物理パラメータを用いて、地震動の経時特性を表現しようとしたも のである。しかし、これらの手法は点震源を仮定しているため、断 層面との位置関係を考慮した設計用地震動の作成には適していな い。これに対し、断層の震源破壊過程をインパルス列としてモデル 化し、震源・伝播経路・地盤増幅の各特性の群遅延時間を合成する ことにより、位相特性をシミュレートした模挻地震動を作成する手 法も提案されている ${ }^{14)}$ 。しかし論文中にも記述されているように、 この手法では、震源が遠くにあり伝播経路特性が複雑な場合には、 主要動以降の継続波部分が適切に評価できないという問題点があ る。また震源近傍の地震動評価に限っても、一般的にはインパルス 列の設定は難しく、実用的見地からすると、この点も解決されるべ き課題であると考えられる。

以上のように、位相情報を用いて設計用模擬地震動に経時特性を 与える研究は、群遅延時間の平均值・標準偏差を統計的に処理する 手法が主流であり、小領域に分割した断層面でインパルス列を想定 する手法が新しい試みとして位固付けられる。しかし前者は、断層 面の広がりや局所的なサイト特性を考虑することが難しく、また後 者は、遠距離地震の適切な評価ができず、また震源破壊過程の想定 も難しく実用性という観点で問題が残っている。

このような研究状況の下で、位相特性設定に関する、より明快で 且つ実用的な考え方の提示が期待されている。筆者らは、既往の研 究とは異なる視点で位相差分分布について考察し、これに基づいた 観測地震動記録の分析を踏まえて位相特性の選択基準を示し、模擬 地震動の経時特性を論理的に決定するための考え方を提案するこ とを目指している。ここでは、そのための基礎となる位相差分分布 について考察する。

本論文の目的は、位相特性を考慮した設計用模擬地震動の作成を 前提とし、位相差分分布と経時特性の関係に関する理論的背景を明 らかにすることにある。本論文ではまず、波形の重ね合わせという、 より直接的で感覚的にも捉えやすい概念を用いて、位相差分分布と 地震動経時特性の類似性について説明する。次に、この概念を用い て位相差分分布とパルス波の関倸について論ずるとともに、初期位 相が経時特性に与える影響に関しても、より論理的な考え方を示す。 更に、地震応答はフーリエ振幅のみならずフーリエ位相にも大きく 依存していることを例示し、模擬地震動の作成にあたっては振幅特 性のみでなく、位相特性も合理的判断に基づいて設定する必要があ ることを指摘する。

\section{2. 位相差分分布の物理的意味}

地震動時刻歴 $f(t)$ は有限フーリエ級数に展開すれば、次式のよう に表現される。

$$
f(t)=\sum_{k=0}^{N / 2} a_{k} \cos \left(\omega_{k} t+\phi_{k}\right)
$$

ここに、 $a_{k}$ は $k$ 次のフーリエ振幅、 $\phi_{k}$ は $k$ 次のフーリエ位相、 $\omega_{k}$
は $k$ 次の円振動数、 $N$ は離散化された時刻歴のデータ数を表す。 但し 0 次は非振動成分であるので、 $\omega_{0}=\phi_{0}=0$ とする。この記号を 用いて、隣り合うフーリエ位相の差である位相差分 $\Delta \phi_{k}$ は以下のよ うに定義される。

$$
\Delta \phi_{k}=\phi_{k+1}-\phi_{k} \quad(k=1,2, \cdots, N / 2-1)
$$

但し、 $\Delta \phi_{k}$ は区間 $[0,-2 \pi]$ の値とする。

区間 $[0,-2 \pi]$ を均等に分割し、位相差分の区間毎の頻度分布を表 した図が位相差分分布であり、この形状と地震動包絡形の類似性が 指摘されている ${ }^{4}$ 。図 1 に、1968 年十勝沖地震八戸港湾 $\mathrm{EW}$ 成分 (以 下、HACHINOHE EW と称する。）及び 1995 年兵庫県南部地震神 戸海洋気象台 NS 成分（以下、JMA KOBE NS と称する。）の時刻 歴波形と位相差分分布の比較を示すが、この例でもその類似性は明 らかである。なお本論文では文献 4)と同様に、位相差分の区間 $[0,-2 \pi]$ を 32 等分し、また頻度分布に関しては、パワースペクト ルの低次からの累積が $99 \%$ となる匴囲までの振動数成分について

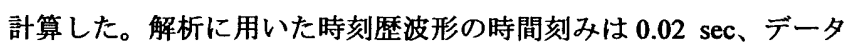

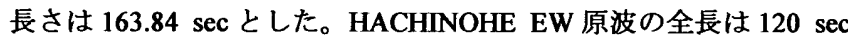
であるので、後続のぜロを付加してデータ長さを調整した。
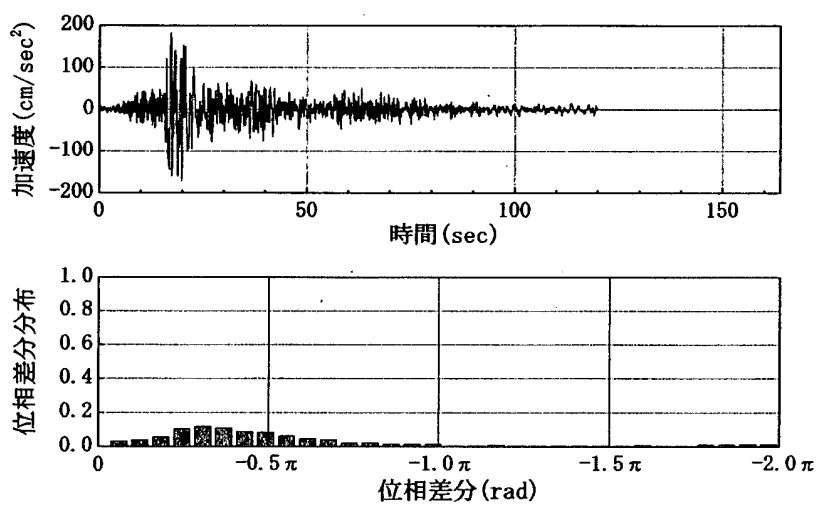

(a) HACHINOHE EW
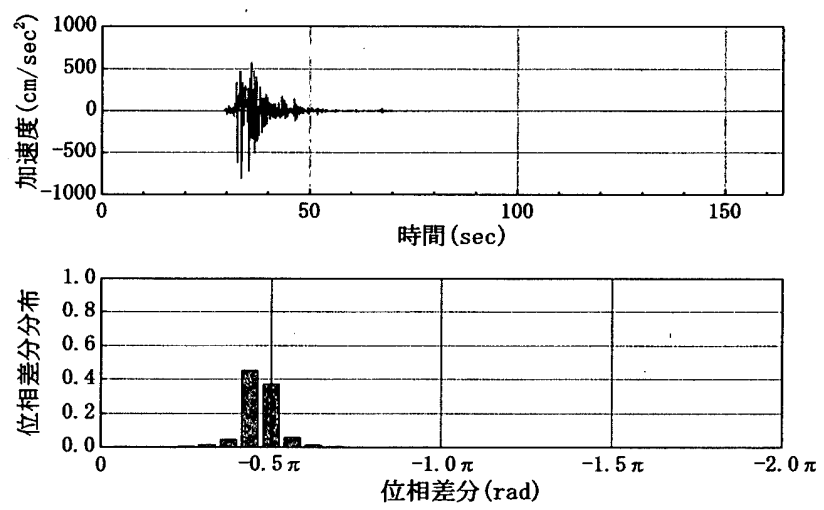

(b) JMA KOBE NS

図 1 位相差分分布と時刻歷波形の比較

次に、位相差分分布のもつ物理的意味について考察する。

式(1)の任意の隣り合う成分波を重ね合わせると、その合成波は以 下のように記述される。但し、ここでは位相差分分布のもつ性質を 明らかにすることが目的であるため、フーリエ振幅は共に 1.0 と仮 定する。 


$$
\begin{aligned}
& \cos \left(\omega_{k+1} t+\phi_{k+1}\right)+\cos \left(\omega_{k} t+\phi_{k}\right) \\
&= 2 \cos \left(\frac{\omega_{k+1}-\omega_{k}}{2} t+\frac{\phi_{k+1}-\phi_{k}}{2}\right) \cos \left(\frac{\omega_{k+1}+\omega_{k}}{2} t+\frac{\phi_{k+1}+\phi_{k}}{2}\right) \\
&(k=1, \cdots, N / 2-1)
\end{aligned}
$$

ここで隣り合う円振動数の差が小さいことを考慮すると、式(3)右辺 の第 1 因子である $\cos$ 関数の周期は長く、これは、第 2 因子の $\cos$ 関 数が円振動数 $\left(\omega_{k+1}+\omega_{k}\right) / 2$ で単振動する波形に、第 1 因子で与えら れる包絡形を乗じた振幅特性を有する波形、すなわち「うなり」と なる。円振動数の差分 $\Delta \omega$ と波形の全長 $T(\mathrm{sec})$ との間には式(4)の関 係があるので、式(3)の包絡関数の周期は $2 T$ となるが、この関俰は 次数 $k$ に依存しないため、隣り合う成分波の合成波の包絡形はす心 て、全長 $2 T$ の cos 関数となる。

$$
\Delta \omega=\omega_{k+1}-\omega_{k}=2 \pi / T
$$

次に、このうなりの振幅が最大となる、いわゆる「腹」の位置に ついて検討する。時間軸上での腹の位置を $\bar{t}$ と表し、 $\Delta \phi_{k}$ 及び $\Delta \omega の$ 記号を用いると、式(3)の包絡関数が最大となる条件は以下のように 記述される。

$$
\Delta \omega \bar{t}+\Delta \phi_{k}=0
$$

ここで式(4)を考慮すると、以下の関俰式が得られる。

$$
\frac{\bar{t}}{T}=-\frac{\Delta \phi_{k}}{2 \pi}
$$

これは、時刻歴波形の任意の隣り合う成分波を抽出し重ね合わせた 場合、うなりの腹の位置 $\bar{\imath}$ と全長 $T$ との比率が、位相差分の符号を 反転させた値 $-\Delta \phi_{k}$ と $2 \pi$ との比率に等しいことを意味する。換言す れぼ、全長 $T$ を $2 \pi$ に対応させると、最大振幅が発生する時間軸上 の位置 $゙$ はー $\Delta \phi_{k}$ に対応寸ることになる。なお、式(2)で $\Delta \phi_{k}$.の区間 を負の領域 $[0,-2 \pi]$ としているのは、式(6)の対応関係を時間軸の正 の領域で成り立たせるためである。

以上の概念を説明したものが図 2 である。ここでは全長を 40.96 sec とし、隣り合う成分波の位相ずれの状況を把握しやすい例とし て、10 次と 11 次の隣り合う成分波の重ね合わせについて示した。 左側の図が隣り合う成分波、右側の図が合成波及びその包絡関数で ある。位相差分は、 $\Delta \phi=0,-\pi / 2,-\pi,-3 \pi / 2$ の 4 ケースとしたが、 この図より、式(6)で与えられる、位相差分とうなりの腹の位置との 対応関係が理解できる。

なお、隣り、合う成分波の振幅が異なるときには、うなりの節の位 置での振幅は完全にはぜ口とならず、この部分でくびれた形状とな る。くびれの程度は隣り合う振幅の比率に依存しているが、ここで はその程度に関しては議論せず、時間軸上での腹の位置に着目して 論理を展開する。

本節では、瞵り合う成分波の位相差分が、それらを合成したうな りの腹の、時間軸上での位置に対応していることを指摘した。位相 差分分布は位相差分を区間毎に総計した頻度分布であるから、同一 区間に属する各合成波の最大振幅は、時間軸上のほぼ同じ位置に存 在することになる。また、属している合成波をすべて重ね合わせた 波形を区間毎に比較すると、その最大振幅値に関する傾向は、位相 差分の頻度分布と相似的になると推察することができる。これより、 全成分波の重ね合わせである原波形の経時特性と位相差分分布が 類似したものになると考えることができるが、次節において観測地 震動記録を分析することによりこの考え方の妥当性を検証する。な
お以下の節においては、この位相差分の各区間に属する成分波の集 合を位相差分群と称することにする。
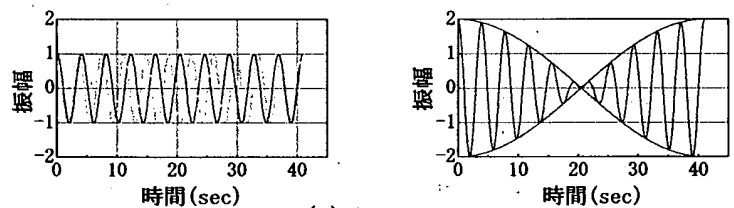

(a) $\Delta \phi=0$
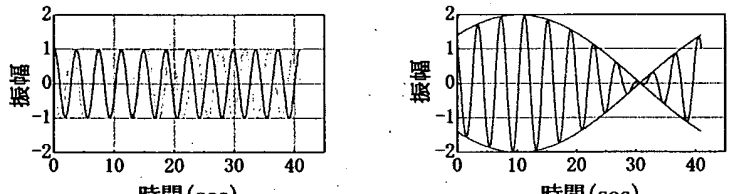

(b) $\Delta \phi=-\pi / 2$
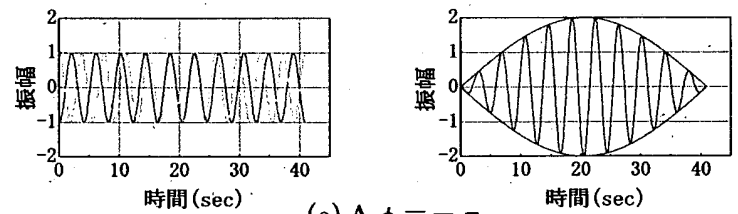

(c) $\Delta \phi=-\pi$
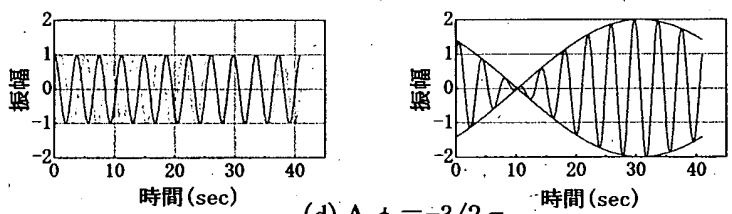

(d) $\Delta \phi=-3 / 2 \pi$

図 2 隣り合う成分波と合成波及びその包絡関数

\section{3. 位相差分群毎のフーリエ振幅・時刻歴波形}

前節の考え方を基にして、一般的な地震動波形の経時特性と位相 差分分布の関係について検討するため、位相差分群毎にフーリエ振 幅・時刻歴波形を求める。

位相差分群に関しては、区間 $[0,-2 \pi]$ を·32 等分していることよ $\eta 、$ 第 $j$ 群の区間を以下のように定義する。

$$
(j-1) \pi / 16 \leq|\Delta \phi|<j \pi / 16 \quad(j=1,2, \cdots, 32)
$$

位相差分分布はこの区間毎の頻度を表しているが、ぞれぞれの群 の内訳として、各群に属する成分波のフーリエ振幅を、振動数を横 軸にして整理した結果が図 3 である。加速度時刻歴としては HACHINOHE EW を用いたが、第 5 群を中心にして第 1〜11 群に成 分波が集中していることは、図1(a)の位相差分分布が第 5 群で最も 高く、これを中心にした第 1 11 群の頻度分布が支配的であること と対応している。また、頻度の高い群ほどフーリエ振幅の值も大き いという傾向が認められる。この図により、各群に属する振動数成 分の全体像を把握することができる。なお、この例ではパワースペ クトルの累積が $99 \%$ となる振動数は約 $7.59 \mathrm{~Hz}$ であった。また、こ のグルーピングは位相差分を基に行っているため、 $(k-1)$ 次と $k$ 次 の位相差分と、 $k$ 次と $(k+1)$ 次の位相差分が異なる場合、 $k$ 次の成 分波は異なる 2 つの群に属することになるが、この場合には、 $k$ 次 のフーリエ振幅は $1 / 2$ ずつ両方の群に振り分けて表示している。

欣に、群に属する成分波をすべて重社合わせた合成波を、図 3 と 同様、群每に整理して図 4 に示す。但し第 17 32 群の加速度波形 の振幅は非常に小さいため、それらの図は省略した。これより、振 

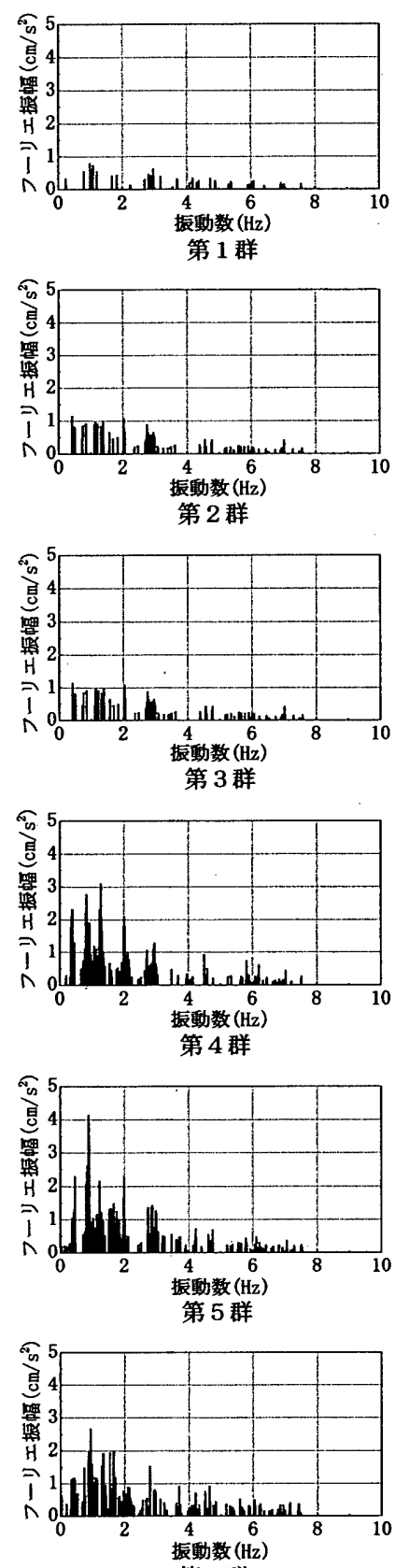

第 6 群

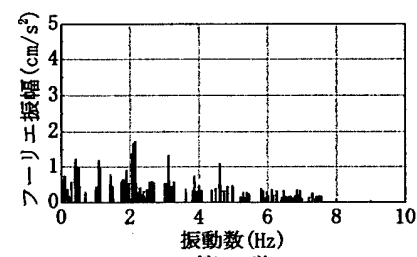

第 7 群

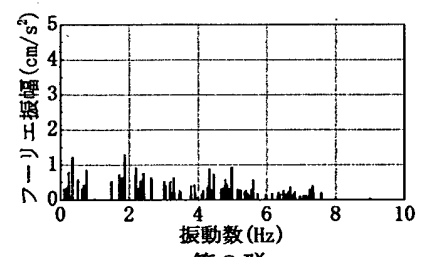

第 8 群
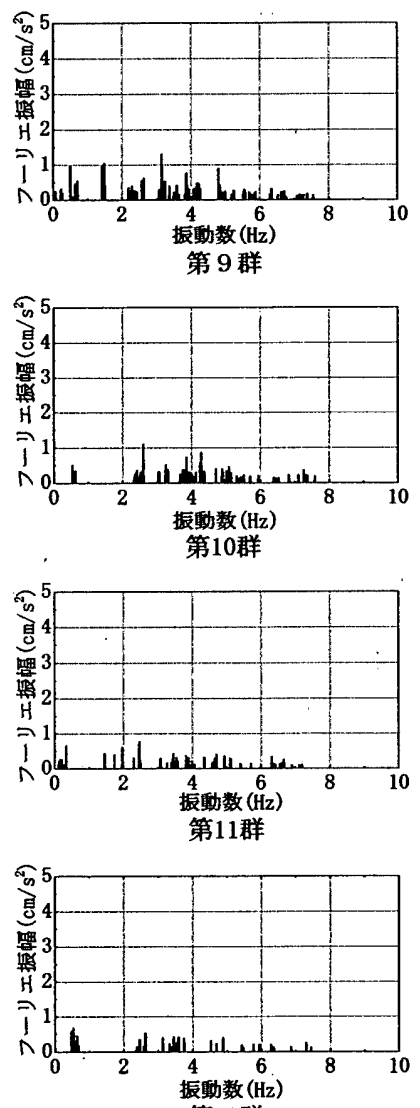

第12群
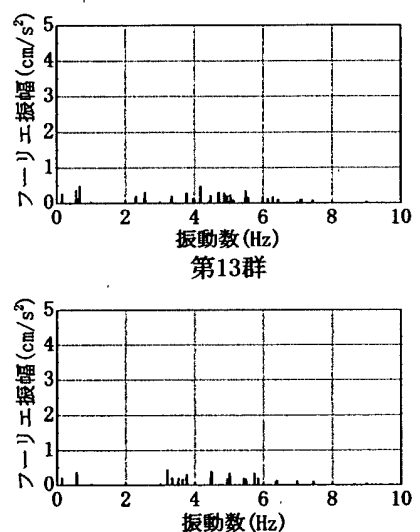

第14群
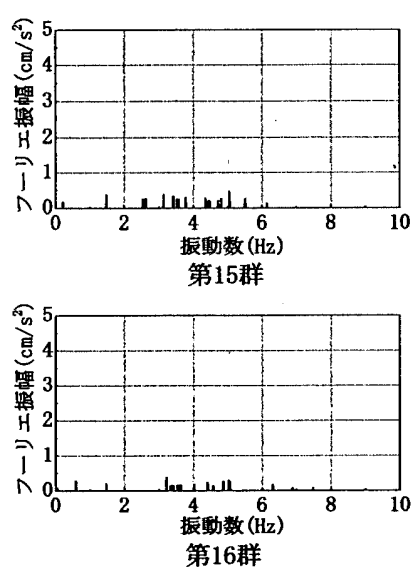
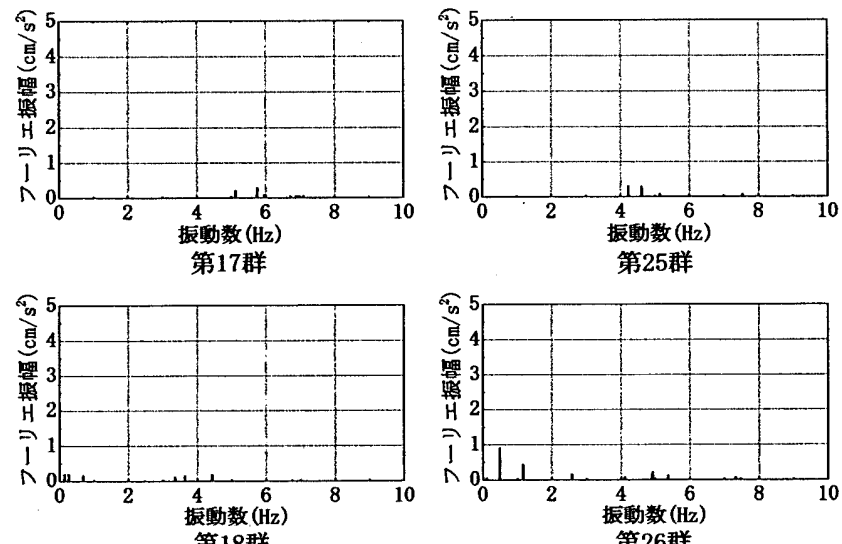

第18群
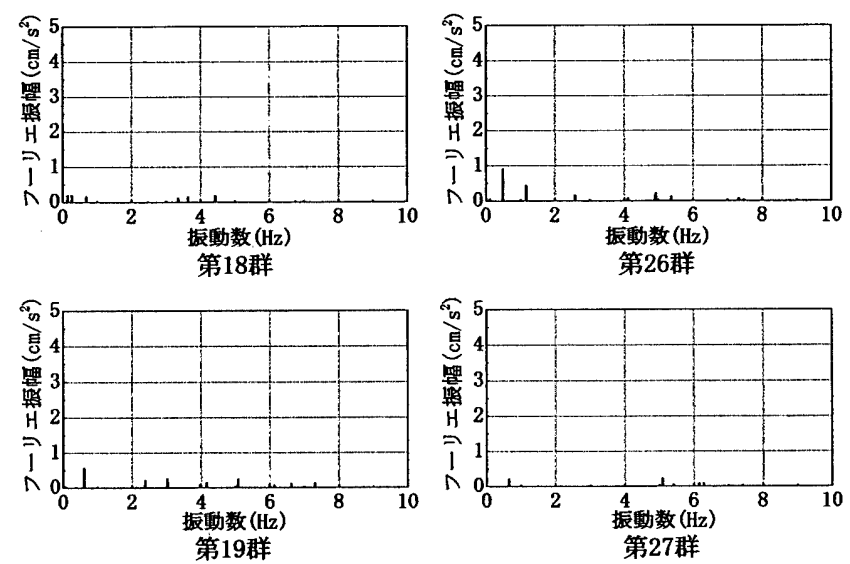

第26群
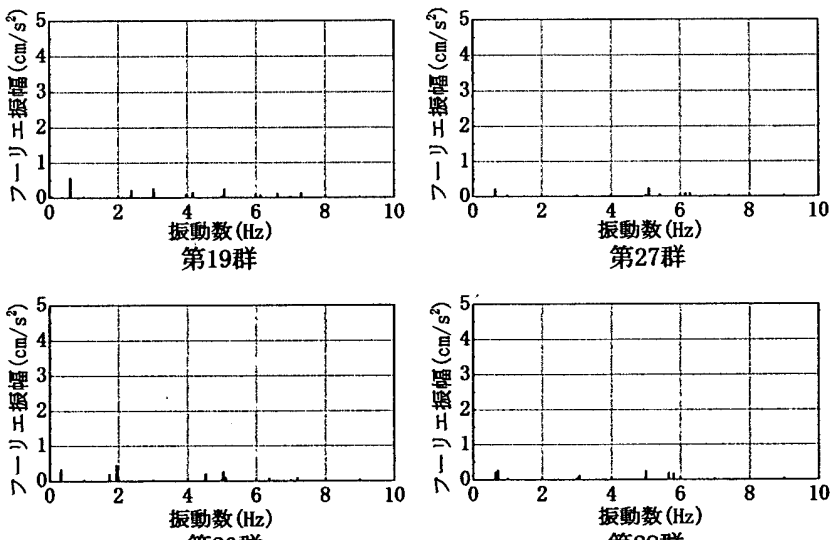

第20群
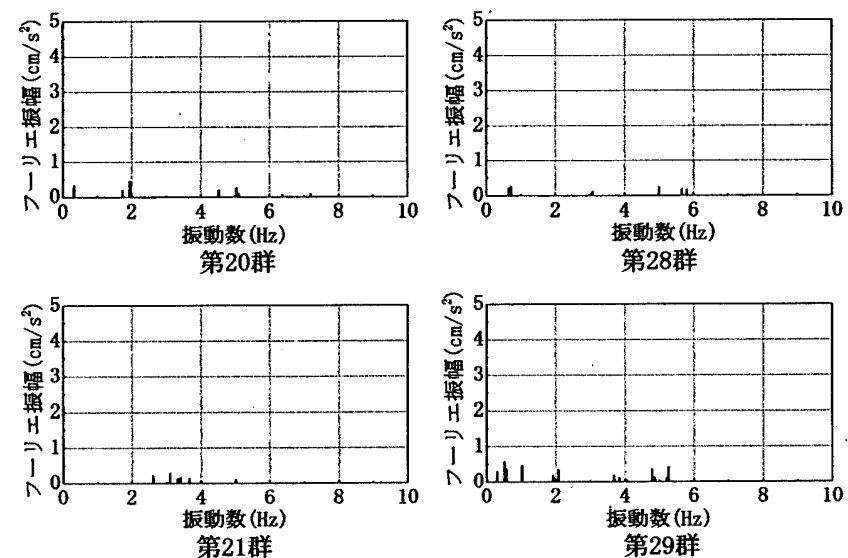

第28群
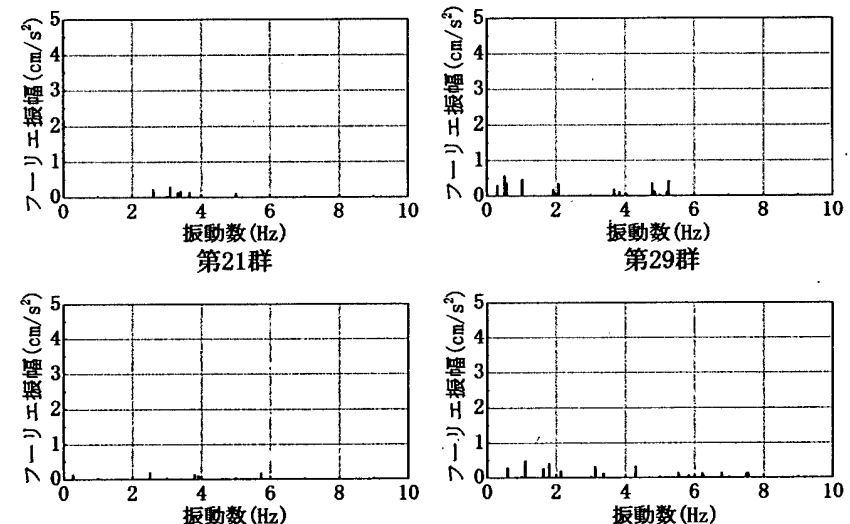

第22群
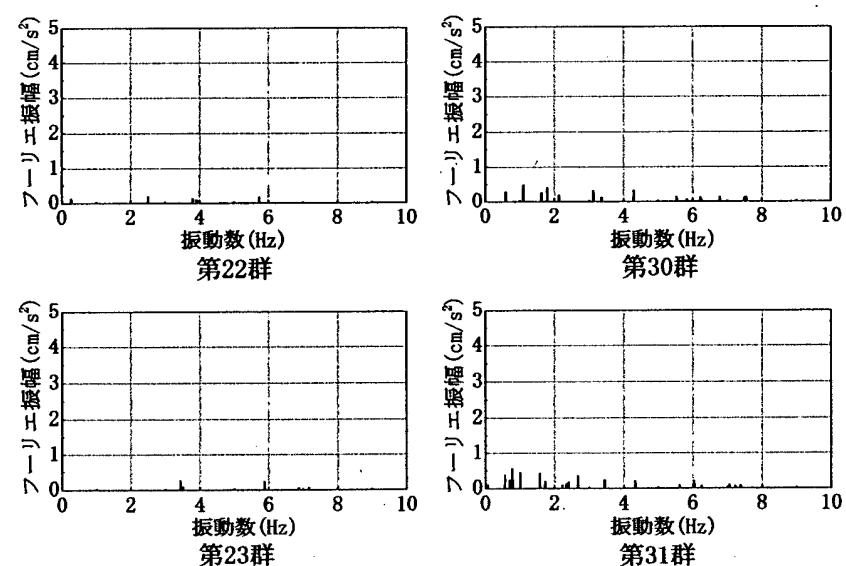

第30群
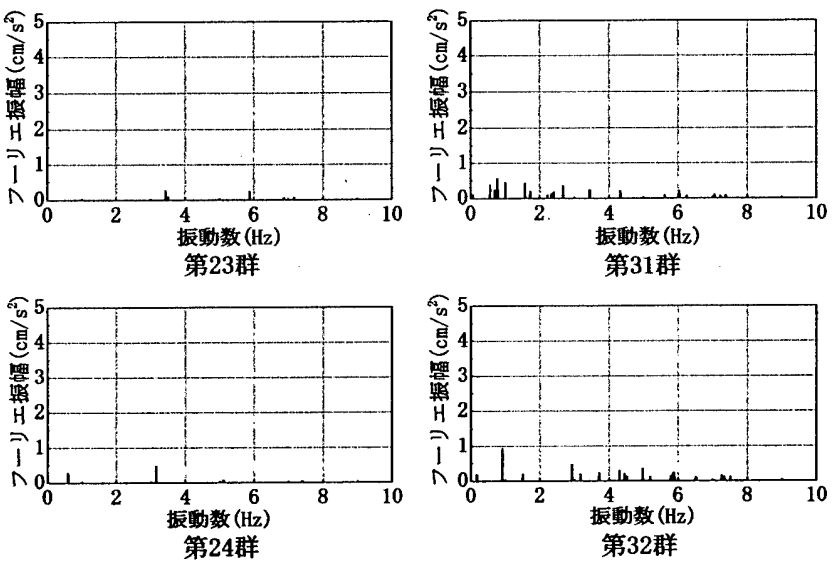

図 3 位相差分群毎のフーリエ振幅（HACHINOHE EW） 

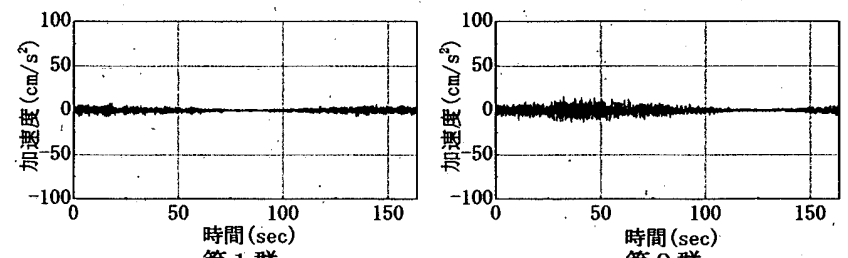

第 9 群
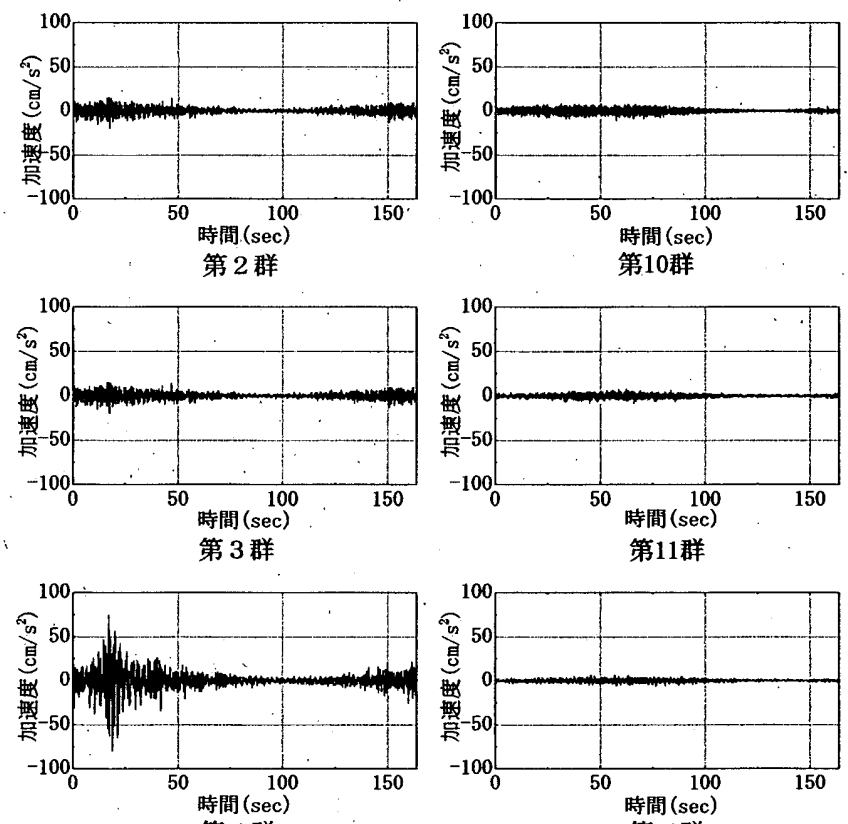
第 4 群

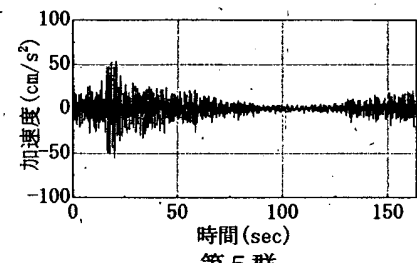

第 5 群

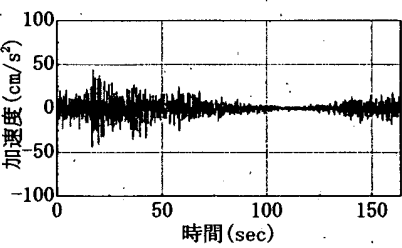

第 6 群

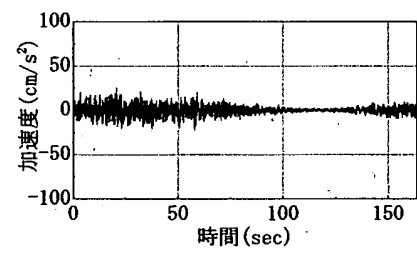

第 7 群

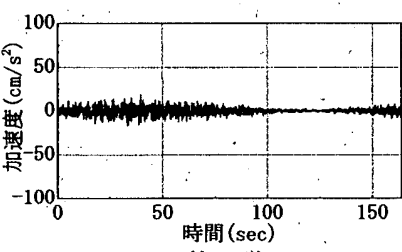

第 8 群

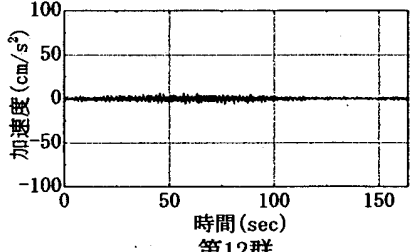

第12群

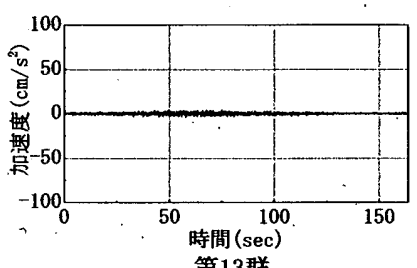

第13群

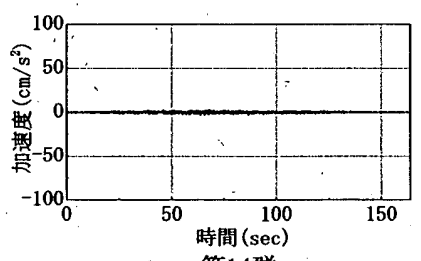

第14群

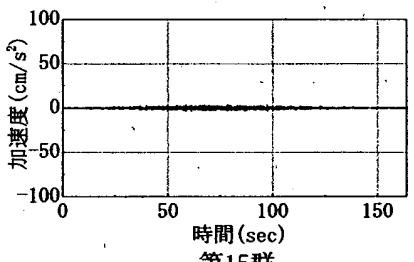

第15群

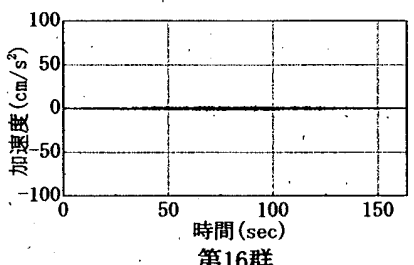

第16群

図 4，位相差分群每の時刻歴波形 (HACHINOHE EW)
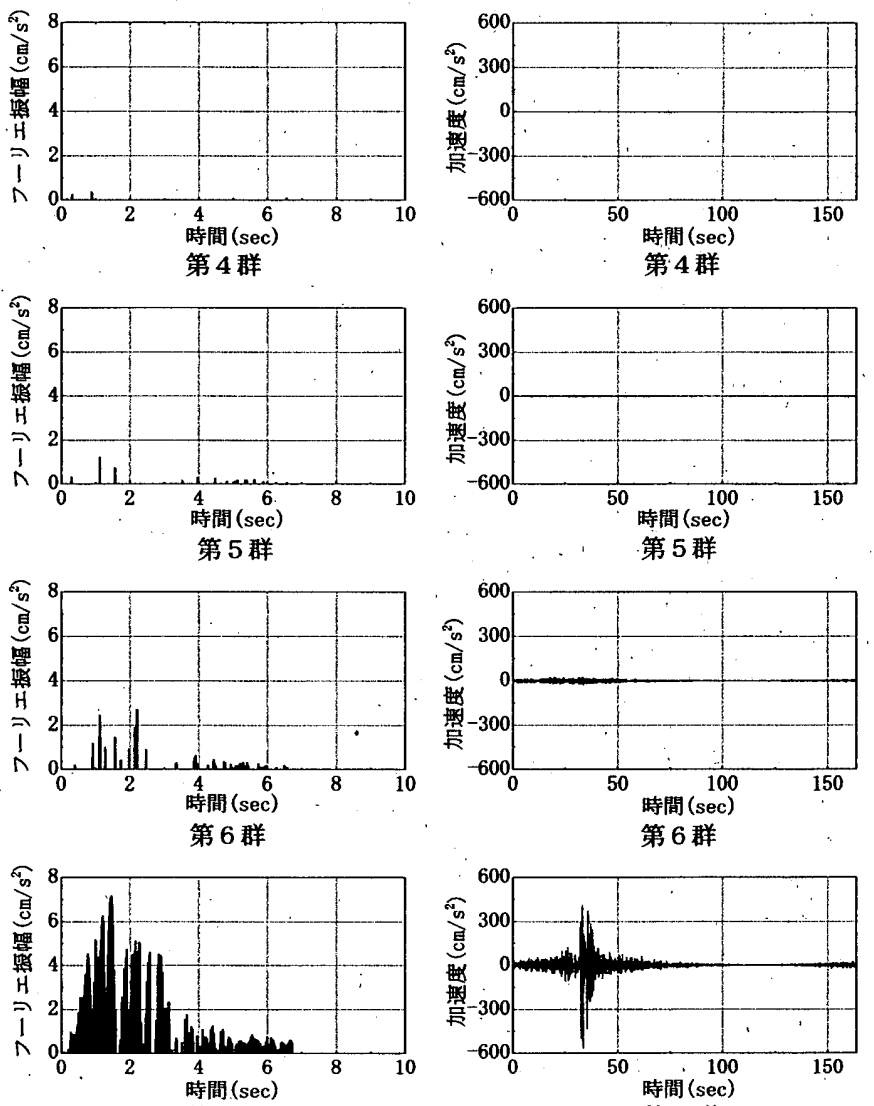

第 7 群
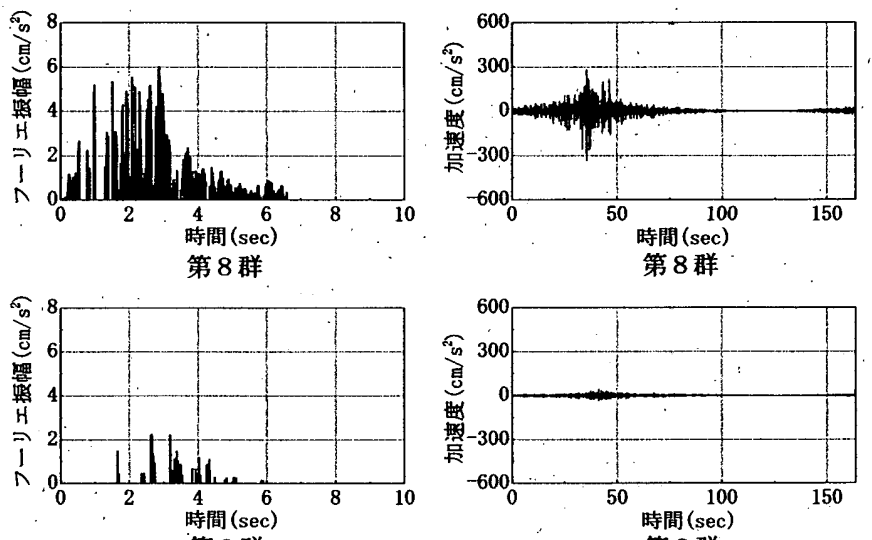

第 9 群
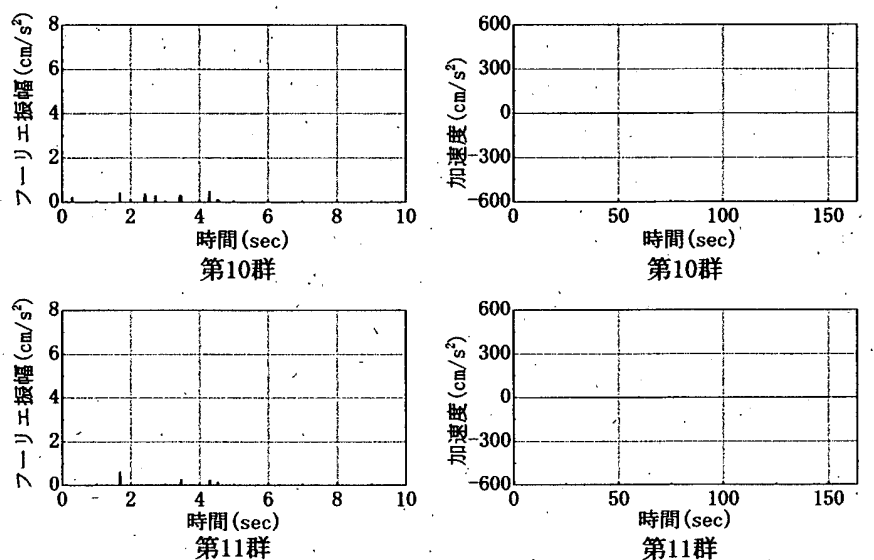

図 5 位相差分群毎のフーリエ振幅 図 6 位相差分群每の時刻歴波形 (JMA KOBE NS) 
幅の大きな群は第 4〜6 群であり、これらが原波形の経時特性に大 きな影響を与えていると指摘できる。また、波形のピークの位置に 関しては以下のような特徴が読み取れる。例えは、、第 4 群の位相差 分は概ね $\Delta \phi=-\pi / 4$ であり、式(6)によると最大振幅は、原点から測 って全長の $1 / 8$ 程度に位置すると想定されるが、図中のピークの位 置はこれに良く対応している。また、第 16 群の位相差分は概ね $\Delta \phi=-\pi$ であり、最大振幅は波形の中央になると考えられるが、図 4 でもその特徴が表れている。振幅の差はあるものの、すべての群 で式(6)の傾向が認められ、位相差分の変化とともにピークの位置が 移動してゆく様子が把握できる。なお、ある成分波が 2 つの群に属 する場合、そのフーリエ振幅を $1 / 2$ として両方の群に振り分けてい るため、各群の時刻歴をすべて重ね合わせた波形は原波形と一致す る。図 4 の各群の波形には時刻 150(sec)前後に比較的大きな振幅が 見られるが、波形を重ね合わせることによりこの部分の振幅は打ち 消しあうため、その合成波は図 1(a)の加速度時刻歴と同じものとな る。

JMA KOBE NS に関して同様の分析を行った結果が、図 5 及び図 6 である。但し図 1(b)の位相差分分布からも明らかなように、第 4 〜11 群以外の頻度分布はほとんど無視できるため、ここでは省略し た。これより、第 $7 、 8$ 群が支配的であり、これらの合成波は、原 点から測って約 $1 / 4$ の位置に大きな振幅を有していることが読み取 れる。これは、これらの群の位相差分が概ね $\Delta \phi=-\pi / 2$ であること に対応している。なおこの例では、パワースペクトルの累積が 99\% となる振動数は約 $6.71 \mathrm{~Hz}$ であった。

以上、包絡形の異なる観測地震動 2 波を分析し、前節の論理の妥 当性を検証した。群每に合成した波形の特性を把挃することにより、 位相差分分布と時刻歴経時特性の関保が、波形の重站合わせという 簡明な概念を用いて物理的・視覚的に理解できることを示した。

\section{4. 一棣位相差分分布とパルス波}

本節では、すべての位相差分が一定であるような位相特性を有す る時刻歴波形について考察する。

ここでもまず、瞵り合う成分波の重ね合わせについて考える。2 節では、式(3)右辺の第 1 因子である $\cos$ 関数、つまりうなりの包絡 関数に着目して、その腹の位置が式(6)で規定されることを示したが、 ここでは第 2 因子の $\cos$ 関数に着目して、局所的な波の形状につい て論ずる。

すべての位相差分が同じである場合、その位相差分を $\Delta \phi 、 1$ 次 の円振動数・フーリエ位相を $\omega_{1}$ 、 $\phi_{1}$ と表すと、 $k$ 次の円振動数と フーリエ位相は次のように記述される。

$$
\begin{aligned}
\omega_{k} & =\omega_{1}+(k-1) \Delta \omega \\
\phi_{k} & =\phi_{1}+(k-1) \Delta \phi
\end{aligned}
$$

この関係式を用いると、ここで注目している $\cos$ 関数は以下のよう に展開される。

$$
\begin{aligned}
& \cos \left(\frac{\omega_{k+1}+\omega_{k}}{2} t+\frac{\phi_{k+1}+\phi_{k}}{2}\right) \\
= & \cos \left(\frac{2 \omega_{1}+(2 k-1) \Delta \omega}{2} t+\frac{2 \phi_{1}+(2 k-1) \Delta \phi}{2}\right) \\
= & \cos \left(\omega_{1} t+\phi_{1}+\frac{2 k-1}{2}(\Delta \omega t+\Delta \phi)\right) \\
& (k=1, \cdots, N / 2-1)
\end{aligned}
$$

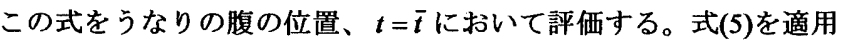

し、 $\omega_{1}=\Delta \omega$ であることを考慮すると、以下の関係式が得られる。

$$
\begin{aligned}
& \cos \left(\frac{\omega_{k+1}+\omega_{k}}{2} \bar{t}+\frac{\phi_{k+1}+\phi_{k}}{2}\right) \\
= & \cos \left(\phi_{1}-\Delta \phi\right) \quad(k=1, \cdots, N / 2-1)
\end{aligned}
$$

すべての成分波閒の位相差分が同一である場合、次数に依らず式 (11)の関保が成立するが、これは $t=\bar{t}$ の位置ですべての成分波が同 位相となることを意味している。言い換えると、 $t=\bar{t}$ の点を原点と みなした場合、すべての成分波は、式(11)右辺の $\cos$ 関数の引数で 与えられる位相角でこの点を通過することになる。このように任意 の点をすべての成分波が同位相で通過する場合には、その点の近傍 で振幅が著しく大きくなり、それ以外の時間領域では成分波が打ち 消しあい振幅が小さくなると予測されるが、ここでは、このような 特徽を有する波をパルス波と定義する。このパルス波を比較対照と して用いる理由は、同一フーリエ振幅を有していても波形の経時特 性が異なること、また弾性応答スペクトルを比較することにより、 地震応答がフーリエ振幅のみならず、位相特性にも大きく依存して いることを明快に理解できるからである。更に本節では、初期位相 と位相差分をパラメータとしてパルス波形の制御が可能であるこ とも示す。

すべての成分波の位相差分が同一である場合には、各成分波は $t=\bar{t}$ の点を同位相で通過することを述へたが、その典型的な例とし て以下の 4 例について検討する。にこでは, 式(11)の引数である、 初期位相 $\phi_{1}$ と位相差分 $\Delta \phi$ の差をパラメータとして分類した。

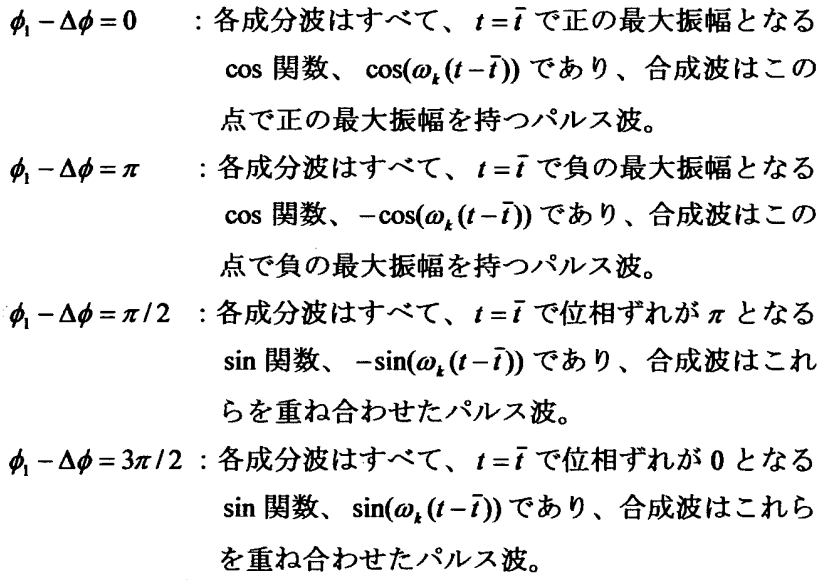
$\cos$ 関数、 $\cos \left(\omega_{k}(t-\bar{t})\right)$ であり、合成波はこの 点で正の最大振幅を持つパルス波。

$\phi_{1}-\Delta \phi=\pi \quad$ : 各成分波はすべて、 $t=\bar{t}$ で負の最大振幅となる $\cos$ 関数、 $-\cos \left(\omega_{k}(t-\bar{t})\right)$ であり、合成波はこの 点で負の最大振幅を持つパルス波。

$\phi_{1}-\Delta \phi=\pi / 2$ : 各成分波はすべて、 $t=\bar{t}$ で位相ずれが $\pi$ となる $\sin$ 関数、 $-\sin \left(\omega_{k}(t-\bar{t})\right)$ であり、合成波はこれ らを重ね合わせたパルス波。

$\phi_{1}-\Delta \phi=3 \pi / 2$ : 各成分波はすべて、 $t=\bar{t}$ で位相ずれが 0 となる $\sin$ 関数、 $\sin \left(\omega_{k}(t-\bar{t})\right)$ であり、合成波はこれら を重ね合わせたパルス波。

以上のように、位相差分がすべて同じ場合、 $t=\bar{t}$ という点はうな りの腹であると同時に、すべての成分波の位相が一致する点、すな わちパルス波の原点になることを示した。またこれは、位相差分分 布の頻度の高い群では、その合成波はある時刻の周辺に大きな振幅 が集中するような波形になることを示唆している。

隣り合う成分波のフーリエ振幅が異なる場合には、うなりの節で 振幅がゼロとならず、くびれたような形状となるが、ここで述べた 関数の特性は振幅值には依存しないため、上記の内容は、任意振幅 の成分波の合成に関して一般性を有している。故に、任意のフーリ エ振幅に対し、すべての位相差分を同一とし、初期位相を上記の条 件式を満足するように与えることにより、指定した時刻の位直に、 
想定した形状のパルス波を発生させることが可能である。

以上、（1）任意のフーリエ振幅を有していても、位相差分を一定 とすることでパルス波の作成が可能であること、(2) 初期位相と位 相差分によりパルス波の形状が制御されることを示した。ここで、 これらの妥当性を検証するとともに、(3) 観測地震動と同一ブーリ エ振幅を有するパルス波の店答性状が原波のものと異なること、つ まり地震応答は位相特性にも依存していることを確㒛する目的で、 以下のようなパルス波を作成し比較検捨を行う。

まず、フーリエ振幅は HACHINOHE EW の特性を採用し、フーリ エ位相として、位相差分が一定となるような特性を与えて作成した 模擬地震動を図 7 に示す。この例ではパルスの位置を全長の $1 / 4$ と することを意図し、位相差分を $\Delta \phi=-\pi / 2$ とした。また前述の 4 条 件に対応させ、初期位相は $\phi_{1}=-\pi / 2,0, \pi / 2, \pi$ の 4 種類とし、その パルス波の形状を比較した。但し、上記 4 条件の記述は内容の関連 性を重視してその順序を決めているのに対し、図 7 では初期位相 $\phi_{1}$ の值の順に波形を並べている。この結果より、フーリ゙ェ振幅の值に 依存せずパルス波を発生させることが可能であること、また、初期 位相と位相差分という 2 個のパラメータを用いることにより、時間 軸上の任意の位置に、想定した形状のパルス波を作成できることが 確認された。

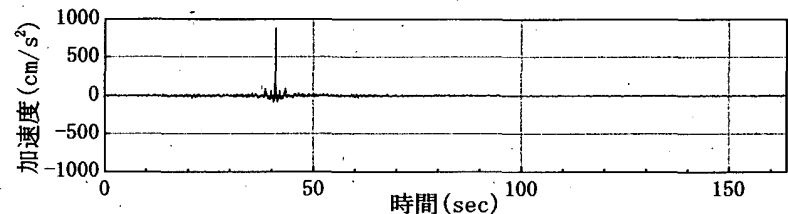

(a) $\phi_{1}=-\pi / 2$

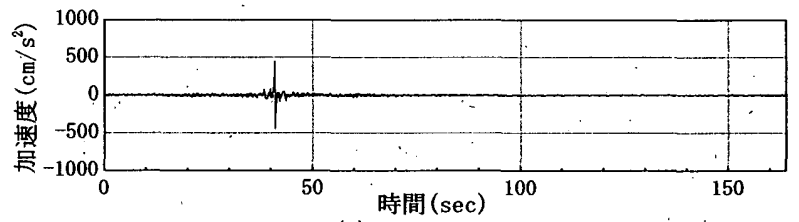

(b) $\phi_{1}=0$

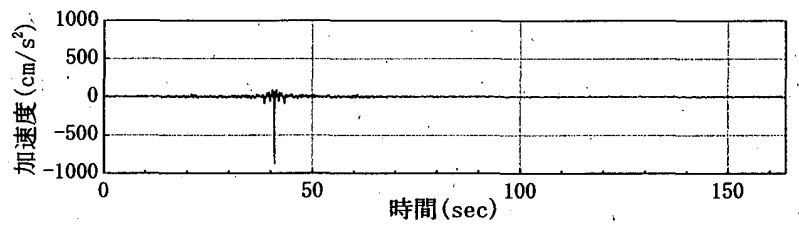

(c) $\phi_{1}=\pi / 2$

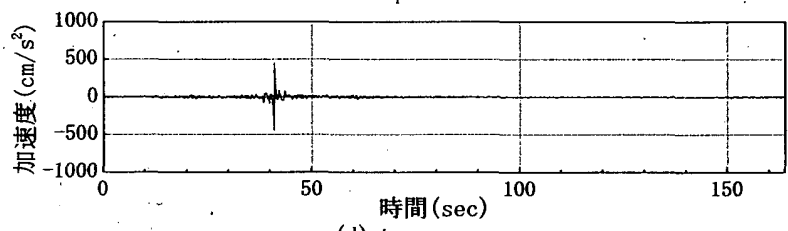

(d) $\phi_{1}=\pi$

図 7 初期位相を変えて発生させたパルス波の時刻歷波形

次に、 $\phi_{1}=0$ のパルス波と原波（HACHINOHE EW）の応答スペ クトルの比較を図 8 に示す。この図は、減衰定数 $h=5 \%$ の線形系 の変位応答スペクトルを基に、擬似速度・擬似加速度忘答スペクト ルを含めて 3 軸対数表示したものである。パルス波の応答スペクト ルは、原波のものに比べ全般的に大きく、特に短周期領域での差異
が著しい。これについては、パルス波は一点ですべての成分波が同 位相で重ね合わされているため、瞬間的な最大応答を表す応答スペ クトルがより大きくなると説明することができる。このように、全 く同じフーリエ振幅を有しているにもかかからず応答值が大きく 異なること、つまり、位相特性の違いが応答に大きな影堹を与えて いることが例証された。また図 9 には、エネルギースペク、トル ${ }^{15)}$ の比較を示す。これは、减衰定数 $h=10 \%$ の線形系の、解析終了時 刻における総入力エネルギーを速度換算したものである。この図で は両者はほぼ完全に重なっており、継続時間全体にわたって累皘寸 る入力エネルギーは、位相特性の違いによる影響をほとんど受けな いことが確認された。

このように位相特性が地震応答に与える影響は大きく、設計用模 擬地震動作成にあたっても、これを適切に評価しなければならない と考えられる。

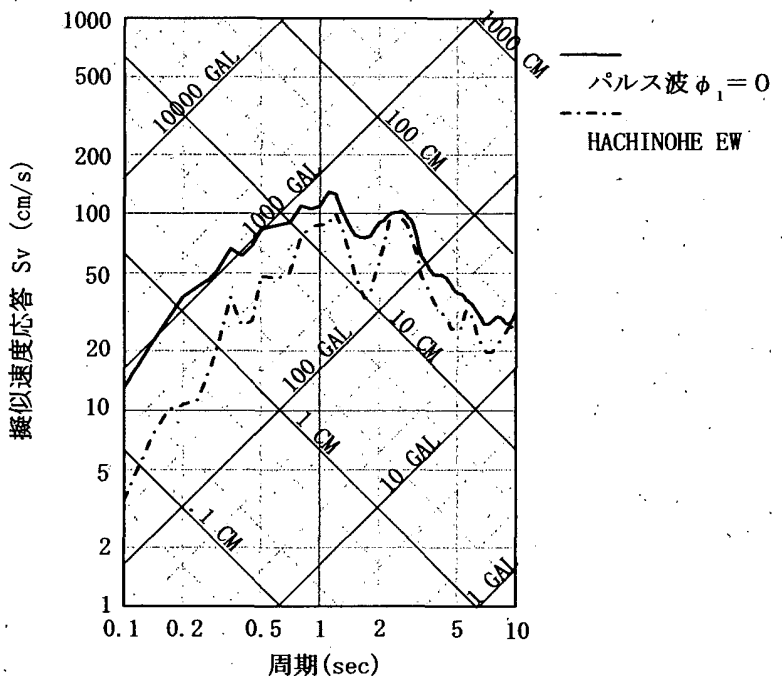

図 8 同一フーリエ振幅を有するパルス波と原波の 擬似速度応答スペクトル $(h=5 \%)$ の比較

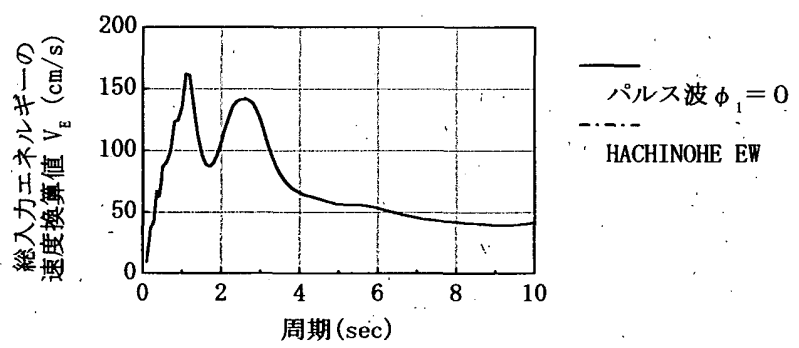

図 9 同一フーリエ振幅を有するパルス波と原波の エネルギースペクトル $(h=10 \%)$ の比較

\section{5. 結論}

位相特性を考慮した設計用模擬地震動を作成する目的で、地震動 の位相差分分布が有する物理的意味について考察し、以下の結論を 得た。

（1）うなりの概念を用いることにより、位相差分分布と地震動経時 特性の類似性に関する理論的背景を明らかにした。すなわち、 瞵り合う成分波の位相差分が、うなりの腹の位置に対応するこ 
とを指摘し、波形の重ね合わせという物理的に明快な論理によ り、その類似性が説明できることを示した。

（2）観測地震動の位相差分を分析し、同一位相差分群（位相差分の 近い成分波の集合）に属寸る波の合成波が、うなりの性状を有 していることを確認した。また、頻度分布が相対的に高い位相 差分群の合成波が原波形の経時特性に支配的な影響を与えて いること、各群の合成波の重ね合わせで原波形の経時特性がよ り直接的・視覚的に説明し得ることを指摘した。

（3）位相差分がすべての成分波間で一定である場合、その合成波は フーリエ振幅に体らず、パルス波となることを指摘した。すな わち、うなりの概念を用いることにより、このような合成波は、 うなりの腹の位置で著しく大きな振幅を有するパルス波を形 成することを示した。

（4）更に、そのパルス波の経時特性が初期位相と位相差分の差に訨 って決まることを指摘し、この 2 個のパラメータを操作するこ とにより、時間軸上の任意の位置に、想定した形状のパルス波 を発生させ得ることを例示した。従来経験的に指摘されていた 初期位相と波形制御の関係について、より論理的な考え方を提 示した。

（5）フーリエ振幅が同一であっても、位相特性により弾性応答スペ クトルが大きく異なること、つまり、地震応答はフーリエ振幅 のみならず、フーリエ位相にも大きく侤存していることを例証 した。この結果は、設計用模擬地震動の作成にあたっては振幅 特性のみでなく、位相特性も合理的判断に基ついて設定する必 要があることを示唆している。

\section{謝辞}

本研究では、港湾技術研究所の強震観測データ並びに気象庁 87 型電磁式強震計データを利用させていただきました。関係各位に感 謝いたします。また論文執筆に関して、（株）日建設計構造設計室 山本恵市氏に御協力いただきました。ここに謝意を表します。

\section{参考文䏻}

1) Jennings, P. C., G. W. Housner and N. C. Tsai : Simulated Earthquake Motions for Design Purposes, Proc. $4^{\text {th }}$ World Conference on Earthquake Engineering, Vol.1, pp.145-160, 1969.1

2) Gasparini, D. A. and E. H. Vanmarcke : Simulated Earthquake Motions Compatible with Prescribed Response Spectra, M.I.T. Department of Civil Engineering Research Report R76-4, Order No. 527, 1976.1

3) 北村春幸, 山根尚志, 村上勝英, 寺本隆幸 : 観湖地震動の位相特性を用い た設計用人工地震動について（その 1,2 ），日本建築学会大会学術講演 梗摡集 (中国)，pp. 287-290, 1990.10

4) 大崎順彦，岩崎良二，大川出，政尾亭 : 地震波の位相特性とその店用に関 する研究, 第 5 回日本地震工学シンポジウム講演集, pp. 201-208, 1978. 11

5) 和泉正哲, 睠倉裕 : 地震動の位相情報に関する基䔎的研究，日本建築学会 諭文報告集，第 327 号, pp. 20-28，1983.5

6) 木村正彦: 模擬地震動作成における波形制御について，日本建築学会構造 系論文報告集，第 367 号, pp. 30-36, 1986.9

7) 沢田勉 : 位相差分による地震動の非定常性の解析, 土木学会論文集, 第 $344 /$ I-1 号, 1984.4

8）沢田勉, 永江正広, 平尾潔 : 位相差分による地震動継続時間の定義とその 統計解析，土木学会論文集，第 368/I-5 号，1986.4

9) 石井透, 神田順, 岩崎良二: 狭带城位相特性を考慮した建築設計用模擬地 震動作成手法, 日本建穼学会構造系論文報告集, 第 379 号, pp. 49-57, 1987.9

10) 佐藤智美, 佐藤俊明, 植竹富一, 菅原良次 : 群途延時間を用いたやや長周
期地震動の経時特性評価のための基硞的研究, 日本建築学会桙造系論文集, 第 480 号, pp. 57-65, 1996.2

11) 佐藤智美, 植竹富一, 菅原良欣 : 群荤延時間を用いたやや長周期地震動の 経験的経時特性モデルに関する研究，日本建築学会践造系論文集，第 493 号, pp. 31-39, 1997.3

12）佐藤忠信, 室野㣚隆, 西村昭彦 : 観沺波に基つく地震動の位相スペクトル のモデル化, 土木学会論文集, No.640/I-50, pp. 119-130, 2000. 1

13）佐藤忠信, 室野㣚隆 : 位相情報を用いた地震動のシミュレーション法, 士 木学会論文集, No. 675/I-55, pp. 113-123, 2001. 4

14）佐藤忠信, 室野剛隆，西村昭彦: 震源・后播・地点特性を考虑した地震動 の位相スペクトルのモデル化, 土木学会論文集, No. 612/I-46, pp. 201-213, 1999. 1

15) 加藤勉, 秋山宏 : 強震による構造物へのエネルキ入力と構造物の損傷, 日 本建築学会論文報告集，第 235 号，pp. 9-18，1975.9

（2001年 7 月 10 日原稿受理，2001年11月21日採用決定） 